\title{
Using a concept cartoon $\odot$ method to address elementary school students' ideas about natural phenomena
}

\author{
Michaela Minárechová \\ Department of School Pedagogy, Trnava University, Trnava, Slovakia \\ For correspondence: michaela.minarechova@gmail.com
}

\begin{abstract}
This study investigated the identification and subsequent development or modification of students' ideas about scientific phenomena by teaching by concept cartoons $\odot$ method. We found out ideas of students of the fourth grade of primary school by conceptual tasks which were parts of quasi-experiment (pretest and posttest desing). For triangulation purposes, we have used additional research methods (observation, analysis of worksheets). We have found out by the overall evaluation of partial investigations (quasi-experiment, observation, analysis of worksheets) that it is possible to develop / modify children's naive ideas through the application of concept cartoons ( $)$ method to teaching of science in primary school. We carried out observations of teacher and students which were focused on evaluation of work with concept cartoons@ method. We also identified some problems of teacher with concept cartoons@ method in instruction.
\end{abstract}

Keywords: concept cartoons $₫$, conceptual change, elementary school students, misconceptions, science teaching

\section{Introduction}

At present, there is a debate about the crisis in respect to the actual realization of science education. This reality subsequently reflects not too good a position of science and attitudes of students to science or placement in bottom most rankings in international tests. This is backed up by the 2007 Rocard report which is accepted by the European Commision as consultation to the level of science education in Europe (Rocard et.al. 2007).

The causes for this state of affairs are complex: there are many elements as a less engaging quality of teaching in comparison, content which is too male-orientated or the quality of the teaching (Osborne, \& Dillon, 2008).

Teachers often present the definition or concept to students. Subsequently, they require this definition from them in the same form. As a result of this process, they are memorizing facts and complex "axioms" without a deeper understanding. This leads to aversion to science and its unpopularity among students. We could regard this as the origin of a domino effect which in turn negatively affects the attitude of students towards science and the inability to use scientific knowledge in everyday life. It is therefore necessary to change the teaching of subjects and instead of transferring the information to develop students' thinking we can lead them to so-called discipline of thought, there is a need for analysing situations differently in order to retain the details required to learn.

One of the promoting solutions of this situation is seen in the application of the inductive method of acquiring knowledge, i.e. students' first work with phenomenon and only after they generalize of the information. This approach covers a number of teaching methods - for example Inquiry-Based Science Education (IBSE), problem-based learning, project-based learning, discovery learning (Prince \& Felder, 2006). Although in the Slovak schools constantly dominate deductive method of teaching 
(Held, Žoldošová, Orolínová, Juricová, \& Kotuláková, 2011), the inductive method is becoming increasingly popular. On the other hand, real implementation of inductive methods in the classroom is rather limited in most countries: "Textbook science dominates and activities are more likely to be only hands-on rather than also minds-on. There is a need for inquiry teaching methods which have a lower threshold for teachers, which teachers are confident to start using and which still have the important key features of reasoning with evidence and reasoning with concepts and recognizing and understanding different points of view" (p.1, Kruit, Berg, \& Wu, 2012).

These requirements are complied with concept cartoons@ method (Naylor \& Keogh, 1999; Naylor, Keogh \& Downing, 2007).

\section{Concept Cartoons@ and conceptual change}

Concept cartoons (C) is a method which is based on the visual display of everyday situations (see. Figure 1). This situation is supplemented with the different views of fictional characters (3-5 characters). Individual statements of these characters support formation of conflicts which lead discussants to argumentation. This way they try to promote their own opinion to explain of observed phenomenon - encourage scientific thinking.

There are ideas which are presented to students in such a way that may undermine their existing ideas. This may lead to inception of cognitive conflict and subsequently to modification of student's ideas. The process of modification ideas is implemented through conceptual change. However the conceptual change is very complex process. The most ordinary analysis is that there are two types of conceptual change, variously called assimilation, weak knowledge restructuring, or conceptual capture and accommodation, strong/radical knowledge restructuring, or conceptual exchange (Duit, \& Treagust 2003). Students' ideas are based on their subjective experiences and beliefs, and explain them the world around them. But these conceptions are not in accord with the way that scientists understood our world. These scientifically incorrect conceptions have been given numerous names, such as, misconceptions, preconceptions, naïve conceptions, alternative conceptions and alternative frameworks (Guest, 2003). However ideas of students are very resistant to change. There is a need to do some initiative or a turn in their previous thinking. We are talking about inducing of cognitive conflict that disturbs and disputes the student's current expectations. There are many authors who have dealt with conceptual change: Piaget (1977), Kuhn (1970), Posner (1982), Hewson (1992), Carey (2000). We can say that many of their theories of conceptual change are a combination of two theories - one from Kuhn (1977) and one from Piaget (1977).

Also the views presented by fictional characters are mostly naive and usually one of them is scientifically acceptable. However concept cartoons (c) do not have only one "right answer". Other views are not illogical - they appear to be logical, correct and acceptable for pupils. These statements arise from research of preconception under study preconceptions - the most common children' views were inserted into the images in the form of statements. 

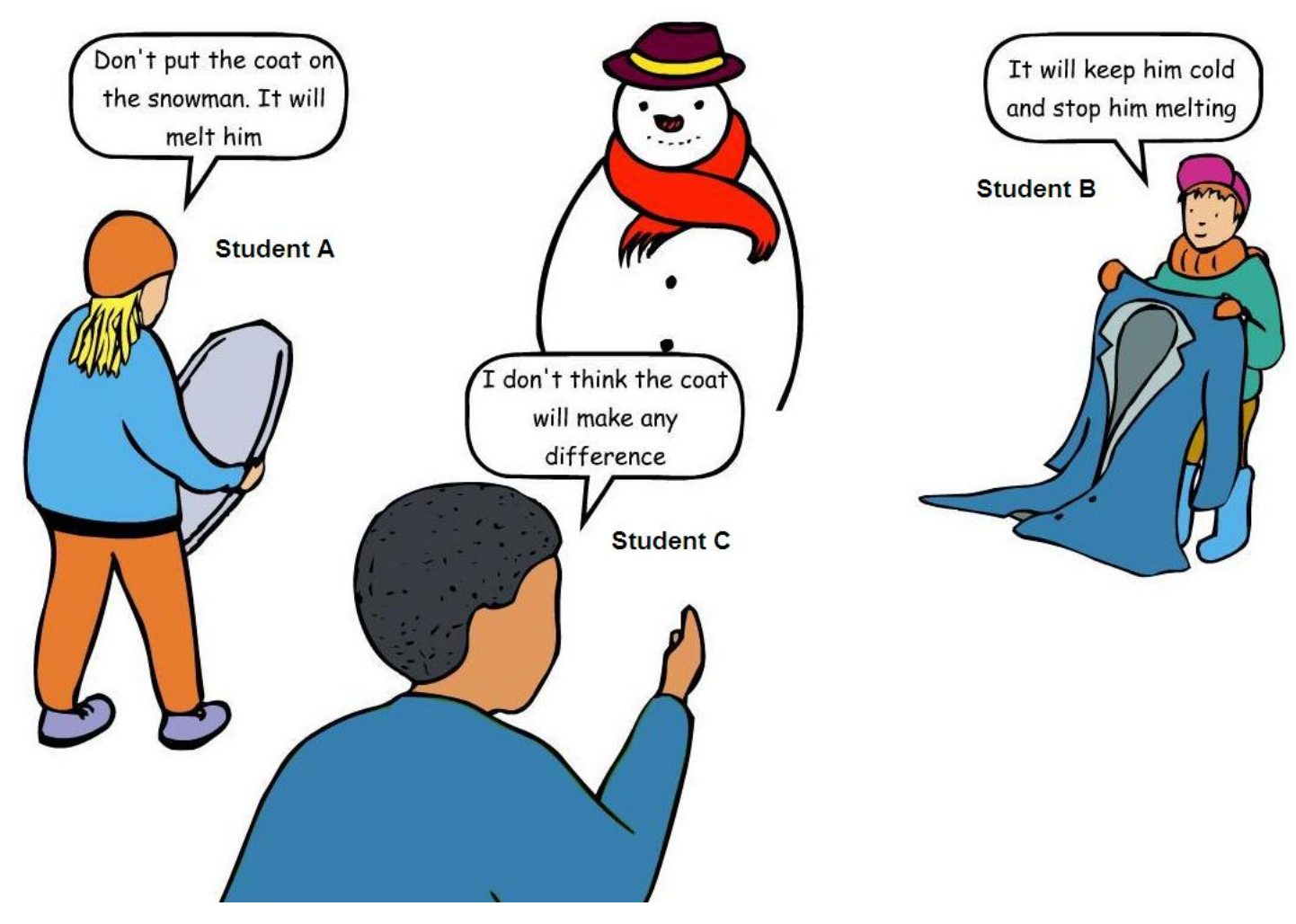

Figure 1 Snowman (Keogh \& Naylor, 2000)

In this study we deal with inductive approach in science education specifically in teaching science through the concept cartoons (): students by own activities attain results and conclusions of their examinations (from specific to general) and the role of teacher in this process of learning is a facilitator and helps students connect their ideas.

We have chosen the following procedure to work with concept cartoons@: First, teacher shows to students a picture with an empty dialog bubbles and ask them what they think about the situation in the picture. Then teacher shows them a picture with filled dialog bubbles and invite students a think about the content of individual bubbles (the teacher asks the students explaining and justifying their claims). After discussions in the groups teacher prompts students to present their opinions of the display phenomenon (students can present their opinions or incline to the views of fictional characters in the picture). In the next step, students suggest draft of procedure for verification of their assumptions which are then implemented.

We also used worksheets in each topic which we have created (its structure were the same in each worksheets).

Example of tasks in worksheet Snowman:

Task 1: What happens to the snowman if it will dress coat?

Task 2: Talk to the group, which statements do you think is true and why?

Task 3: Design to procedure how you can verify your statement (you state specific equipments, materials and what you expect to happen)

Task 4: Try to write a conclusion of what you found in this examination.

Due to the absence of relevant research in Slovak conditions, we would like to examine the relationship between teaching science through concept cartoons $\odot$ and the development of scientific ideas. We think that our findings could also help other countries in enhancing of science education. 


\section{Research Part}

Research is focused on the application of the concept cartoons@ to teaching of science in the 4th year of school for three months (from September 2013 - to December 2013). In this time, there were taught nine scientific themes in both groups (in EG by concept cartoons@; in CG by traditional way of teaching). Teacher in experimental group got nine pictures of concept cartoons@. She was acquainted with the working procedure with concept cartoons@ method.

The main objective of study (O1) was to examine the relationship between teaching science through concept cartoons (C) and the development of scientific ideas of students. We have tried to identify the relationship between variables: independent variable (teaching through concept cartoons (C) and dependent variable (ideas of students).

Another objective of research was to determine the work of teacher with concept cartoons (C) method (O2).

We set research questions (RQ) based on the stated objectives (O1 and O2) of research:

RQ1: Is it possible to modify children's naive ideas through the application of concept cartoons (C) to teaching of science?

RQ2: Which problems does teacher have in teaching through concept cartoons@?

\section{The research sample}

In order to monitor the effect of work with concept cartoons $\left(C_{1}\right.$, it was necessary to implement it. Due to the complexity of the subject, the search of schools willing to participate in research was very limited. It was also very problematic for both teacher, and for the overall organization of the subject. This study was conducted with a total of 34 students from two class of the fourth grade of elementary school in Trnava's region without a specific concept of teaching. The students had no experience in any inductive methods, nor had the teacher. We didn't find out difference in children's scientific ideas between involved classes. One class comprised experimental group (17students) and one class comprised control group (17 students) of research. It was an in-depth work with the class and the teacher could enter into the organization of subject by adjustment to content of the school curriculum.

\section{Methodology and Research}

The study used pre-test post-test quasi experimental research design whose implementation can be explained by the following scheme: 


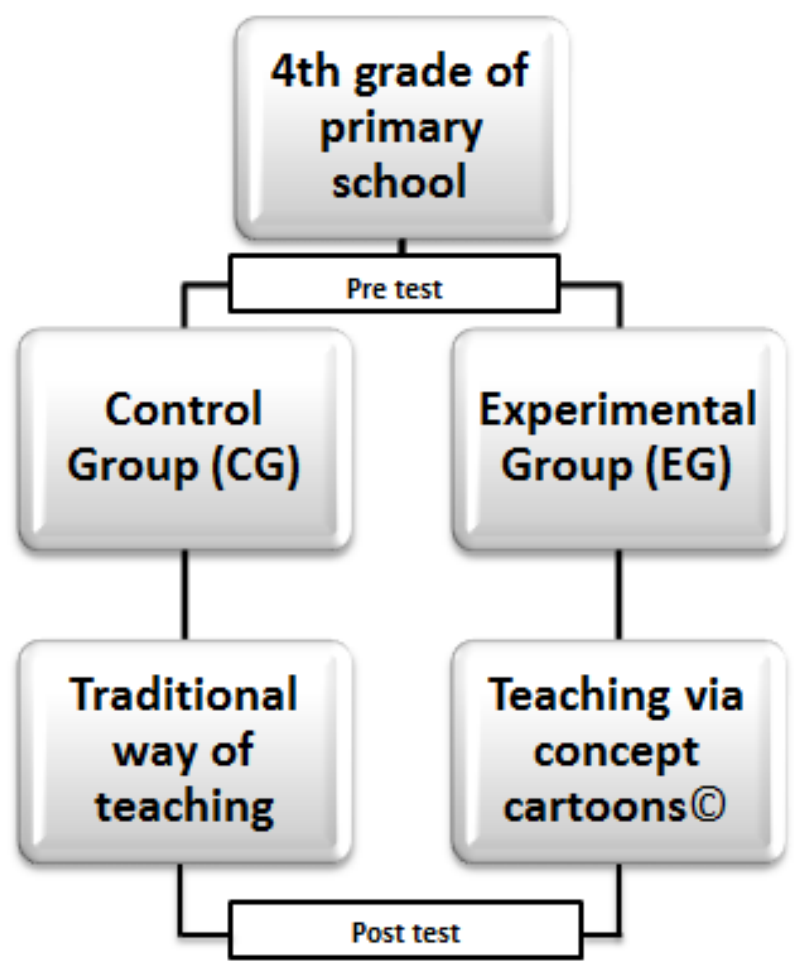

Figure 2. Design of pedagogical experiment

Because we worked with the whole class (groups are considered non-equivalent as groups are not randomized, Cohen et al., 2007) which are called intact groups, research was of the quasi experiment nature.

For scheme 2, the procedure of research can be explained as follows: We applied pretest in the both classes which consist of conceptual tasks. These tasks were designed to identify the level of students' ideas about science phenomena. Then involved classes of 4th grade were divided into two groups (the control, CG and experimental group, EG). The experimental group was taught by concept cartoons $\subseteq$ and the control group was taught by traditional way of teaching. After approximately three months of teaching in this manner, the students were tested again with the same test (posttest).

Before the implementation of the research we conducted pre-research. By this pre-research we verified and elaborated of research tools and methods which were later used in the research.

We focused on content analysis in evaluating of the pretest and posttest. We can apply different quantification methods in content analysis such as monitoring frequency of analytical categories, analysis of contingency and the analysis of intensity. In this way, the quality is given by contents of the selected analytical categories and converted to a quantitative extent. We focused on findings of the frequency of occurrence of the selected category in students' statement.

First we focused on the analysis of particular categories which were found in students' answers in pretest. Subsequently we focused on the frequency occurrence of each categories in the pretest in both groups (EG / CG).

We proceed the same way in the processing of the students' responses of both groups in the posttest as in the pretest. Firstly we focused on the analysis of categories in individual stundets and then to frequency of occurrence of each categories in all item in both groups (EG/CG). 
Content analysis involves the interaction of two processes: specification of the content characteristics being examined and application of explicit rules for identifying and recording these characteristics. (Stemle, 2001). "The core and central tool of any content analysis is its system of categories" (p.58, Titscher et al., 2000). The analytical units of text are called recording units which incorporates into certain categories. In order to meet the requirements of verifiability and repeatability of the analysis, it was necessary to specify the importance of each category through its indicators We have categorized students' responses in the pretest and posttest according to types of responses adopted from Osuská \& Pupala (1996).

However we have modified the dispose of the particular categories according to specific sequence (from no response through another type of response to the scientifically acceptable answer). Furthermore we have added a category 0 (no response). We have also broadened some definitions of these categories:

0 - No response

1 - Another type of response: This category comprises heterogeneous statements in which students escape from nature of themes, they react unnaturally and respectively they get away from contextual framework of question. Here we classify the responses which recapitulated the wording of the question;

2 - Naive: Naive statements represent the type of statements in which the student produces understandable theory only for him/her. However this response is not compatible with the scientific interpretation but for the student is reasonably explained and he/she evidently believes it.

3 - Wrongly structured: wrongly structured statements are inadequate "processed" scientific information. The student's verbal construction of statement is unconvincing even for the student himself. The student during presentation gets into a state of uncertainty, lack of confidence in himself. Within the test tasks we classified here, there were statements that contained elements of scientifically acceptable statements but in incompatible scientific combinations.

4 -Dogmatic: in these statements we register a production of the facts as they were presented by teacher in school but without student' subjective addition of reasoning, assessment and rationalizing. It is often the reproductions of definitions- such as "rattle rule off" or draw a picture or scheme. However it is without student's understanding of the its meaning.

5 - Scientifically acceptable: there are statements in which the student has a scientifically acceptable explanation (this statement is in accordance with scientific interpretation). It is evident from the student's statement that he/she understands this topic. This is proved as being scientifically acceptable.

Students were given 45 minutes to complete each test. During each 45 -minute test, students worked independently. Pretest and posttest consist of the same questions (12 questions) that cover eleven science topics (see.Tab.1). However there were teaching nine themes in EG and in CG (see second column in Tab.1).

A pretest was administered in September and a posttest given to the students in February. The third column in Table 1 is the number of teaching hours (45 minutes) which were devoted to particular topics. For a more thorough investigation of the effectiveness of concept cartoons@ in the modification (development) of students' preconceptions, we applied the same pretest and posttest. In these tests were moreover topics which were not taught in any groups (magnetism). By this step we would like to find out whether the development of students' preconceptions was caused by applying the concept cartoons $@$ or not. 
Table 1 Science topics used in the test and in the teaching

\begin{tabular}{lcc}
\hline \multicolumn{1}{c}{ Topic (pretest, posttest) } & Teaching & Number of teaching hours \\
\hline $\begin{array}{l}\text { Thermal conductivity of } \\
\text { materials }\end{array}$ & Yes & 1 \\
\hline Density of matter & Yes & 1,5 \\
\hline $\begin{array}{l}\text { Sensory systems of human } \\
\text { (vision) }\end{array}$ & Yes & 1 \\
\hline $\begin{array}{l}\text { Sensory systems of human } \\
\text { (hearing) }\end{array}$ & Yes & 1,5 \\
\hline $\begin{array}{l}\text { Circulatory system of } \\
\text { human }\end{array}$ & Yes & 1,5 \\
\hline Inclined plane & Yes & - \\
\hline Gravity & - & 1 \\
\hline Electricity & Yes & - \\
\hline Magnetism & - & 2 \\
\hline Friction & Yes & 2 \\
\hline Cosmos & Yes & \\
\hline
\end{tabular}

For triangulation purposes, we have used several means to investigate to achieve the given objectives and to obtain the most relevant data. We used the following research methods in research:

- Analysis of worksheets in which we focused on the ideas of students about particular topic we focused on the analysis of worksheets from some students. The students were selected by the targeted selection: condition for selection was participation of students in all lessons as well as their attendance in a pretest and posttest. We focused on the ideas of students about teaching topics. These ideas we coded by the above stated five analytical categories. Then we calculated the frequency of occurrence of these categories in worksheets and compared it with results of posttest. We analysed three students who participated in all science lessons which were taught through concept cartoons $\odot$. We focused on four items in the worksheets: 1. Their views on the situation shown in picture of concept cartoons@ with empty dialog bubbles; 2. Opinion of the groups of students of statements of fictional characters; 3 . Draft of procedure for verification of students' assumptions; 4 . Conclusion - what the student found out by his/her examination.

- Direct structured observation which was focused on teaching activities of teacher and the activities of students, specifically to teacher's work with the concept cartoons $\odot$ method and communication of students - we used direct structured observation focused on the work of teacher and communication of students in groups during teaching concept cartoons $\mathbb{C}$. We observed each science lessons which were touched by concept cartoons@ $\bigcirc$. We used adapted observational tools (used in project Fibonacci, see Carulla, 2012) which were focused on activities of teachers and students in groups - specifically for teacher with concept cartoons (C) and communication of students. We focused on registering the occurrence of events with natural coding.

\section{Results of research}

In the following texts we clarify the results of particular research investigations (quasi-experiment, observation, analysis of worksheets) which we used in research in order to thoroughly verify work with concept cartoons (). 


\section{Quasi-experiment}

We proceed the same way in the processing of the students' responses of both groups in the posttest as in the pretest. Firstly we focused on the analysis of categories in individual students and then to frequency of occurrence of each categories in all item in both groups (EG/CG).

When we compared frequency of occurrence of each categories the students' ideas in the EG and CG we found that students (in both groups) have the most perfect ideas in area of spread of sound and motion of bodies in a gravitational field. In the first area (spread of sound) students did not directly express that it is the spread of sound through a solid environment (particularly by rails). However we can conclude (based on their statements) that they understand this phenomenon and can explain it. We noticed a difference between the groups in area of electricity (EG - 94\% occurrence of correct ideas , CG $-65 \%$ ) and the motion of the Earth (EG - 76\%, CG - 53\%). However we also detected the occurrence of naïve type of students' statements and responses in EG. On the contrary, we noticed more wrongly structured statements in area of the motion of the Earth in CG.

We noticed imperfect ideas in the same areas (in both groups) - density of matter and thermal conductivity of materials. In both groups, the students explained the swimming of a ship mainly to the presence of various components (such as anchor, propellers, etc.) or to its weight (particularly CG). Also in the area of magnetism (question no. 10) we noted responses occurred in both groups which we predominantly classified to the category Other type of statement and Naïve type of statement or students did not answer. When we explored the students' ideas about form of electricity we noticed they were either unanswered or there were a Naive type of response. This topic requires abstract thinking for its understanding, especially the topic of electricity with which students have the least own experiences.

When we compared the students' statements in the EG and CG we found out that EG gained the highest frequency of occurrence of scientifically acceptable statements in all areas. On the other hand in CG it was only in $7^{\text {th }}$ questions (q. no. 2, 3, 6, 7, 8a, 11, 12; see Figure no.3)

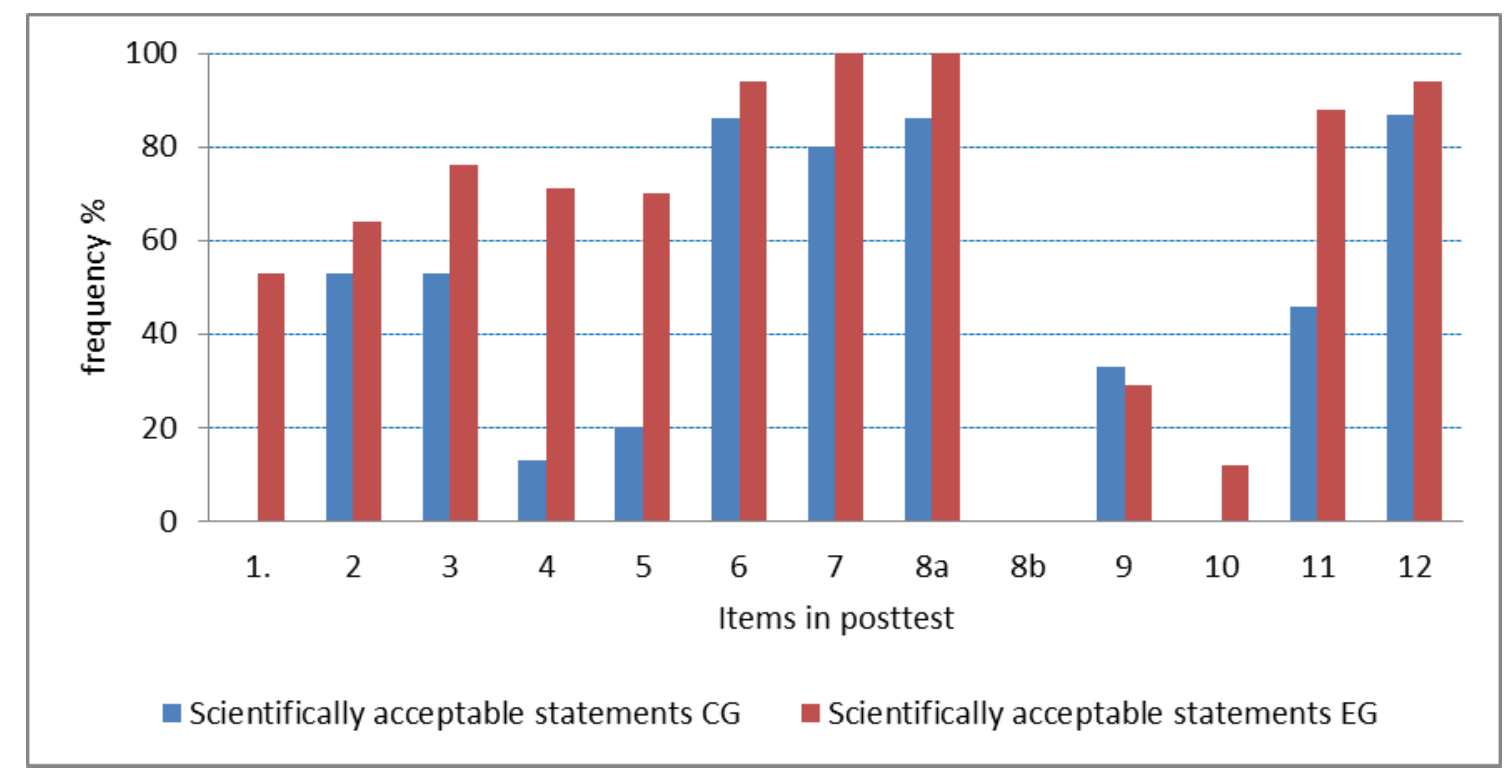

Figure 3. Compare of occurrence of scientifically acceptable statements in Control Group (CG) and Experimental Group (EG) in posttest

Also the individual students in the EG gained a higher frequency of this type of statements as the CG although this category was also leading in individual students in CG (see. Figure no. 4 and 5). 


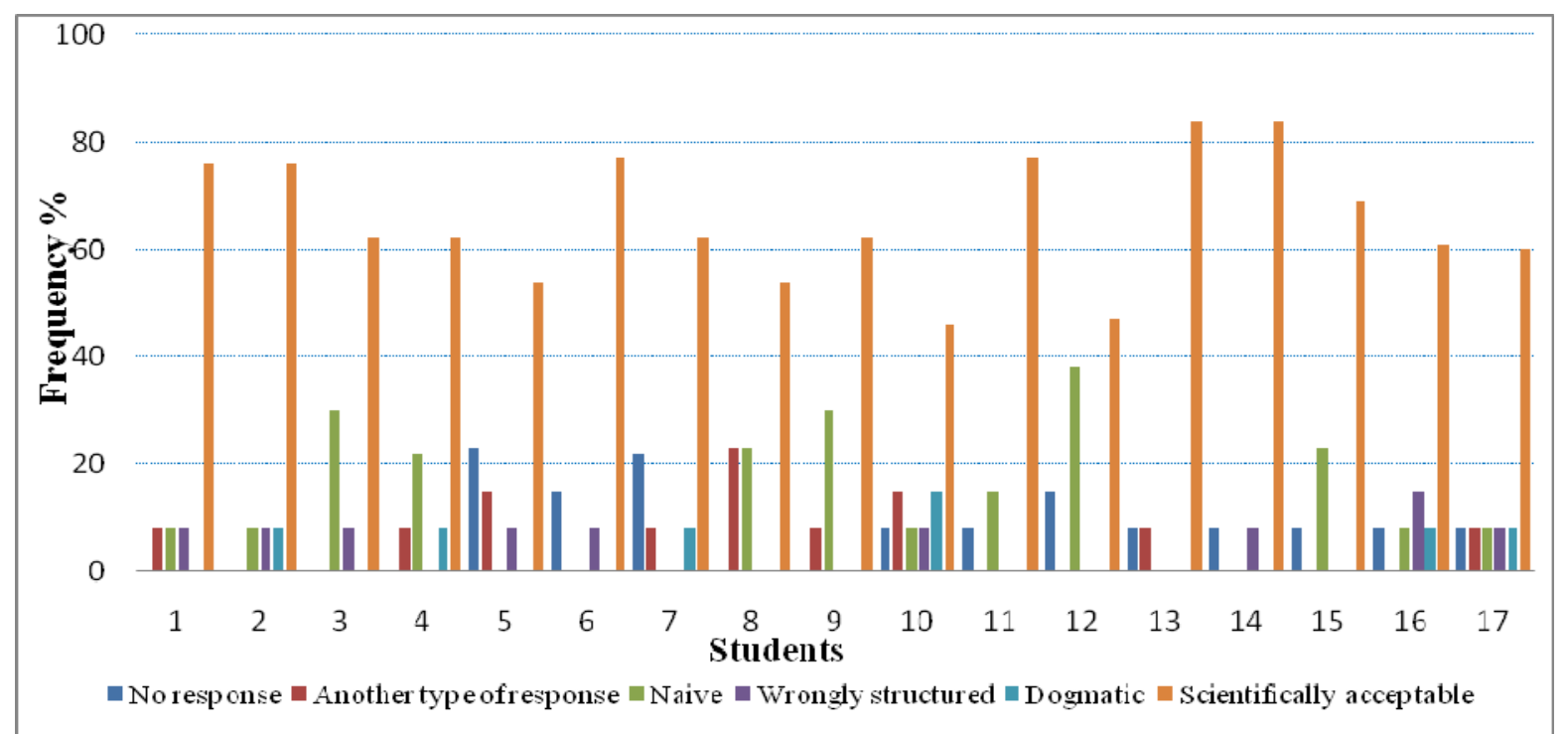

Figure 4. Posttest EG (frequency of occurrence of categories in responses of individual students)

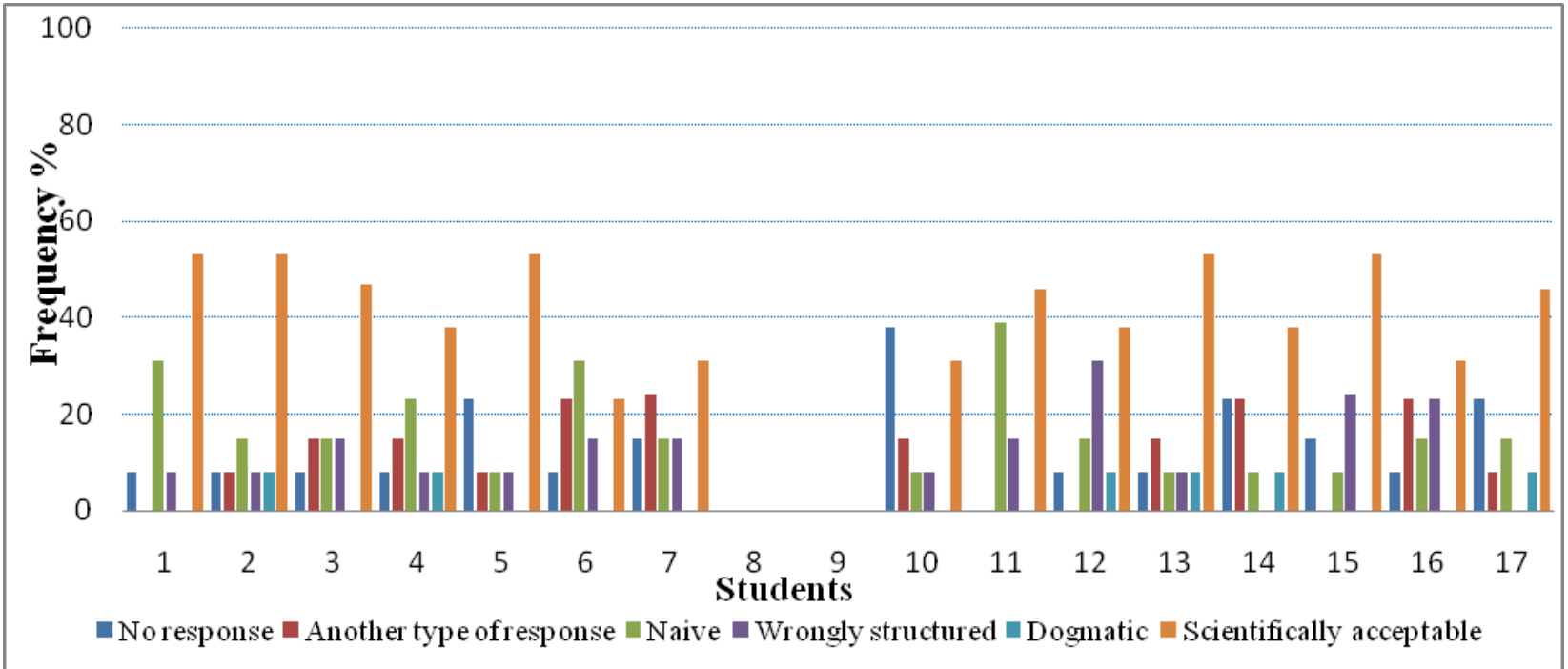

Figure 5. Posttest CG (frequency of occurrence of categories in responses of individual students)

When we compared the ideas of students in the EG and CG we found out that students of both groups have the most perfect ideas in area of friction and motion on an inclined plane (item no. 6), in area of electricity (item no. 8a) and in area of the motion of the Earth (item no. 12 ). The biggest difference in ideas of students was noticed in area of thermal conductivity of materials, sensory systems of human (vision) and the density of matter. In these areas we have not registered any progress or shift in the development of ideas towards its improved versions in CG. Students from this group reported the same type of statements in the posttest as in the pretest. On the contrary, we noticed a shift of students' ideas towards scientifically acceptable statements in EG.

We used t-test for testing the equality of the means of scores in elementary files, because the distribution of scores in the control and experimental group can be considered normally.

Test results were entered to Microsoft Excel. After pre-test, t-test was used to check difference between both groups. After post-test, t-test was used to find the effectiveness of either concept cartoon (C) or traditional method of teaching. 
Table 2 Acceptance/rejection of null hypotheses

\begin{tabular}{|c|c|c|c|c|c|c|}
\hline Hypothesis & Group & $\mathbf{N}$ & Mean & t Stat & $P(T<=t)$ & Decision \\
\hline $\begin{array}{l}\text { There is no statistically } \\
\text { significant } \\
\text { between the students' } \\
\text { pretest scores in the control } \\
\text { group who received } \\
\text { traditional teaching method } \\
\text { and in the experimental } \\
\text { group who was taught by } \\
\text { concept cartoons@. }\end{array}$ & $\begin{array}{l}\text { CG } \\
\text { EG }\end{array}$ & $\begin{array}{l}17 \\
17\end{array}$ & $\begin{array}{l}3,29 \\
3,37\end{array}$ & 0,42 & 0,67 & Accepted \\
\hline $\begin{array}{l}\text { There is no statistically } \\
\text { significant } \\
\text { between the studentsence } \\
\text { posttest scores in the control } \\
\text { group who received } \\
\text { traditional teaching method } \\
\text { and in the experimental } \\
\text { group who was taught by } \\
\text { concept cartoons@. }\end{array}$ & $\frac{C G}{\text { CG }}$ & $\begin{array}{l}\frac{15}{17} \\
\end{array}$ & $\begin{array}{l}3,55 \\
4,18\end{array}$ & 3,88 & 0,0005 & Rejected \\
\hline
\end{tabular}

The comparison of scores was done using t-test. T-test indicates that P-value 0,67 (in pretest) is insignificant at $\alpha 0.05$ level of significance. So the null hypothesis stating that there is no statistically significant difference between the students' pretest scores in the control group who received traditional teaching method and in the experimental group who was taught by concept cartoons $\odot$, is accepted. If we accept the null hypothesis so we reject alternative as the best explanation for the data $\left(\mathrm{H}_{\mathrm{A} 1}\right)$.

The next hypothesis of the study was that there is no statistically significant difference between the students' posttest scores in the control group who received traditional teaching method and in the experimental group who was taught by concept cartoons $\odot$. It showed difference between the mean scores of experimental $(M=4,18)$ and control $(M=3,55)$ groups. The significance of the difference was tested using t-test. T-test indicates that P-value 0,0005 (in posttest) is significant at $\alpha 0.05$ level of significance. If the this P-value is less than 0.05, then we reject the null hypothesis and accept alternative hypothesis ( $\mathrm{H}_{\mathrm{A} 2}$ : There is statistically significant difference between the students' posttest scores in the control group who received traditional teaching method and in the experimental group who was taught by concept cartoons()).

The observations focused on the work of the teacher.

In the observation protocol, we evaluated the frequency of occurrence of the pre-defined activities of the teacher in the classroom during teaching by concept cartoons $@$. The most frequently registered possibilities of particular fields are shown in Table No. 2 (second column). Shown in the last column is the frequency of occurrence of these particular categories (\%).

Table 3 Evaluation of observation (teacher)

\begin{tabular}{llc}
\hline $\begin{array}{l}\text { The observed activities of } \\
\text { a teacher }\end{array}$ & \multicolumn{1}{c}{ Possibility } & $f \%]$ \\
\hline Introduction of activity & $\begin{array}{l}\text { Teacher insufficiently clarified to } \\
\text { students work during the lesson }\end{array}$ & 45 \\
\hline Discussion in classroom & $\begin{array}{l}\text { When teacher saw that the group did } \\
\text { not discuss, she encouraged }\end{array}$ & 78 \\
\hline
\end{tabular}




\begin{tabular}{lll}
\hline & $\begin{array}{l}\text { members of group by a non-invasive } \\
\text { example or evocative questions }\end{array}$ & \\
\hline $\begin{array}{l}\text { Draft of procedure for } \\
\text { verification of students' } \\
\text { assumptions }\end{array}$ & $\begin{array}{l}\text { Teacher suggested draft of procedure } \\
\text { for verification of their assumptions }\end{array}$ & 56 \\
\hline Termination of activity & $\begin{array}{l}\text { The teacher directly used expression, } \\
\text { explanations, conclusions, findings of } \\
\text { students ... }\end{array}$ & 33 \\
& $\begin{array}{l}\text { The teacher did not emphasize the } \\
\text { goal of lesson - she evaluated results } \\
\text { of the discussion or examination of } \\
\text { the established objective ... }\end{array}$ & \\
\hline $\begin{array}{l}\text { The total organization of } \\
\text { the classroom }\end{array}$ & $\begin{array}{l}\text { The teacher did not have problems } \\
\text { with organization of students' } \\
\text { activities in the classroom and in } \\
\text { groups }\end{array}$ & \\
\hline
\end{tabular}

The observations focused on communication of students.

We evaluated the frequency of occurrence of pre- items relating to the communications of students'. We observed one group of students at each lesson. The students were divided into three groups in the class. The composition of these groups was constant for three months. During this period, the teacher taught nine science themes (we observed each group of students for three times).

We focused on two types of evaluation: (a) evaluation in terms of particular groups of students, and (b) evaluation in terms of teaching topics.

In this way we wanted to find out how the communication of the students depended on particular participants of groups and how it depended on the teaching topics.

Based on the observation of the three groups we can say that the communication of students depended especially on teaching topics. It was obvious that they had no problems with presenting their views in topics which they knew (due to them having experience) for example in topic of inclined plane. Their answers were especially spontaneously and they were not encouraged by the teacher. They also participated in whole-class discussions.

Table 4 Evaluation of observation (communication of students)

\begin{tabular}{lll}
\hline Communication of students & possibility & $f[\%]$ \\
\hline Communication in group & $\begin{array}{l}\text { Majority of students are } \\
\text { involved in group discussion } \\
\text { (more than half of the group) }\end{array}$ & 67 \\
\hline Argumentation & $\begin{array}{l}\text { Answers like yes - no (without } \\
\text { explanation ) }\end{array}$ & 67 \\
\hline $\begin{array}{l}\text { Verbal expressions of } \\
\text { students- spokesperson of } \\
\text { group }\end{array}$ & $\begin{array}{l}\text { He answered only the } \\
\text { questions, but several sentences } \\
\text { and adequately }\end{array}$ & 67 \\
\hline $\begin{array}{l}\text { Draft of procedure for } \\
\text { verification of students' } \\
\text { assumptions }\end{array}$ & $\begin{array}{l}\text { Draft of procedure from } \\
\text { teacher }\end{array}$ & 67 \\
\hline Use of scientific terms & Never & 100 \\
\hline
\end{tabular}


Worksheets of students

When we compared the worksheets to posttest we found out the transformation of students' initially imperfect ideas towards its improved versions in some of their answers (at all three students). It was especially in topics of thermal conductivity and density of matters. The students came out from realized practical verifications of their assumptions in their statements. Therefore we can stat that the naïve ideas of students have developed from practical verifications of their initially imperfect ideas and especially in those topics which were new to students.

\section{Summary of Research Results and Recommendations for Practice}

Concept cartoons is relatively broad in the world - it is confirmed by many studies and reports dealing with these issues (Kapabinar, 2005; Dabell 2008; Long and Marson, 2003, etc.). For example Kabapinar (2005) in her article proposes to use the method concept cartoons $\odot$ as:

A) Teaching methods that initiates and encourages class discussion and as

B) Educational material that can be used in the form of posters and worksheets. These can be supplemented by exercises and practical issues.

She also proposed particular phases of the implementation concept cartoons $\odot$ in teaching: "presentation of picture concept cartoons@", "debate about these pictures", "investigation of statements in the pictures", "reinterpreting ideas in pictures through the investigation findings."

Dabell (2008) used the concept cartoons @ in mathematics. In his research, he played with the original concept cartoon formula and adapted the speech bubbles for different concepts and different age groups. For example, one correct speech bubble and three incorrect, two correct speech bubbles and two incorrect or all speech bubbles correct. He also describes the use of concept cartoons@ in the teaching. Firstly, he presented the concept cartoon on the interactive whiteboard. At this stage, he took one or two ideas from children or did a quick survey with the whole class. Then he divides children into small groups. Each group should comment on the statements of each character in the picture. Then groups used 'envoys' - one child from each group visiting another group to discuss their take on things. This takes approximately 5 minutes. Then the envoy returned to his group to share ideas he has picked up. After this phase is the time to open up the debate to the whole class during which the teacher takes the role of "devil's advocate" and calls into question the response of each group. The final phase is encourage students to try for RIP - refine, improve and polish the statements in the cartoons.

In our research we focused on inductive approach in teaching of science subjects specifically in teaching science by concept cartoons $\odot$. Due to the absence of relevant researches in Slovak environment we have decided to investigate relation between teaching of science by concept cartoons $\odot$ and development of scientific ideas in primary school. Also we investigated what problems may have a teacher with concept cartoons@ in teaching.

We realize that the idea of using concept cartoons@ in teaching science is not new (especially in foreign countries like United Kingdom and Turkey). There exist a lot of studies which deal with utilization of this method (Ingec, 2008; Chin, \& Teou, 2010; Kapabinar, 2005; Dabell, 2008). However, majority of these studies deal with utilization concept cartoons $\odot$ in secondary schools and university (especially in teacher candidates).

We have found out by the overall evaluation of partial investigations (quasi-experiment, observation, analysis of worksheets) that it is possible to develop / modify children's naive ideas (RQ1) through the application of concept cartoons (c) to teaching of science. This is also confirmed by the following findings: 
- We registered a shift in the development of initially imperfect ideas towards more sophisticated ideas in some students in the EG. Generally students of the EG achieved higher frequency of scientifically acceptable statements in post test in comparison with students in CG (although it was the predominant type of statements in both groups);

- When we compared the statements of the students in pretest and posttest in both groups we found out that ideas of the students in EG were more developed (modified) especially in the area of thermal conductivity and density of matters. We did not notice the development of students' ideas in CG in these or any other areas. Although there were a decreased number naïve ideas students in CG, on the other hand there was an increased number of wrongly structured ideas;

- In this case the development or modification of the students' ideas depended mainly on the design and implementation of draft to verify students' assumptions.

Furthermore we found out which problems teacher have in teaching through concept cartoons@ (RQ2):

- Based on an observation which was aimed at the teacher working with the concept cartoons@ we can say that the teacher especially supported discussion in class (and in groups). The adaptation of working procedure in the classroom through the concept cartoons () by her own preferences was perceived positively. A negative aspect in the teacher's work with the concept cartoons (C) was that she did not respect and support the students in formation of draft to verify their assumptions. The teacher interrupted "scientific work of students" and this task has taken at oneself. She also tried to influence the right answer for students in verifications their assumptions. So she prevented the students from attaining "right answers" by their own cognitive activities and to possible modification of their imperfect ideas - there may occur a re-ranking of cognitive schemas of student when he/she sees that his/her assumption was confirmed. If the teacher presents his/her "correct answers" to students, so they will present the teacher's version. However they will constantly believe their own original imperfect ideas.

We can mention some contributions for pedagogical practice which emerge from those investigations. We introduced and clarified work with still relatively unknown concept cartoons $@$ in Slovakia. This method can be utilized in the teaching of other subjects such as science (which is confirmed by the activity of the training teachers).

We confirmed the effectiveness of the concept cartoons (C) in the development / modification ideas of students through partial research investigations. We can formulate recommendations for teaching practice particularly for teachers on the basis of activities related to research work (in particular the observation):

- Every teacher should respect the working procedure of its application. This procedure is based on the algorithm of scientific investigation which can be found in inquiry based science education (IBSE: stimulate situation, making predictions, planning and conducting investigations, solving problems, testing ideas, reflecting on new evidence and developing new predictions).

- The teacher should try to praise each presented view of students although it is not scientifically correct. This is so teacher can remove the possible fear among students of presenting their own views.

- The teacher should also try (as much as possible) to support discussion in class and in groups of students. This is possible when the teacher creates a friendly atmosphere in the classroom where nobody mocks the opinion of each other. Moreover he/she should ask students for substantiation and explanation of their arguments especially when they judge statements of 
fictive characters in dialog bubbles and when they create drafts to verify their assumptions and make conclusions.

- In addition every teacher should lead students to the practical verification of their claims, i.e. he/she should not only theoretically discuss it with students but he/she always should ensure the practical realization of practical verification of their assumptions. This way teacher can promote the development of scientific ideas.

It is very important so that the teacher avoids giving his own drafts of procedure for verification of students' assumptions -he/she should let each group of students to realize their own proposals (when it is possible).

The main benefits of research are especially in the performance of concept cartoons $\odot$ to teachers of primary education. These teachers will use concept cartoons@ in their work in future and so they contribute to its insemination in the environment of science education.

\section{References}

Berg, E van den, Kruit, P. and Wu, F. (2012) Getting children to design experiments through concept cartoons. Paper presented at the Fibonacci conference on Inquiry Based Science \& Mathematics Education: Bridging the gap between education research and practice, Leicester, UK. Available at http://kennisbank.hva.nl/document/480167

Carulla, S.B (Ed.). (2012) Tools for Enhancing Inquiry in Science Education. Fibonacci Project, December. http://fibonacci.unibayreuth.de/fileadmin/Dokumente/startingpackage/companion/tools_for_enhancing_inquiry_in_science_education.pd $\mathrm{f}$

Cnin, Ch., Teou., L-Y. 2010. Formative assessment: Using concept cartoon, pupils' drawings, and group discussions to tackle children's ideas about biological inheritance, In Journal of Biological Education, vol.44, no.3, p. 108-115, DOI: $10.1080 / 00219266.2010 .9656206$

Cohen, L., Manion, L., \& Morrison, K. (2007). Research methods in education. New York: Routledge.

Dabell, J. 2008. Using Concept Cartoons. In Mathematics Teaching Incorporating Micromath, 209, p. 34-36.

Duit, R., \& Treagust, D.F. (2003). Conceptual change: a powerful framework for improving science teaching and learning. International Journal of Science Education. 25,671 -688.

Guest, G. 2003. Alternative frameworks and misconceptions in primary science. University of the West of England, Bristol: Bristol, UK.

Held, L., Žoldošová, K., Orolínová, M., Juricová, I. \& Kotuláková, K. (2011). Výskumne ladená koncepcia prírodovedného vzdelávania (IBSE v slovenskom kontexte) [Inquiry-based Science Education (IBSE in Slovak Context)]. Trnava, Slovakia: Typi Universitatis Tyrnaviensis.

Ingec, S., K. 2008. Use of Concept Cartoons as an Assessment Tool in Physics Education. In US-China Education Review, vol.5, no.11, p.47-54.

Kapabinar, F. 2005. Effectiveness of Teaching via Concept Cartoons from the Point of View of Constructivist Approach. In Educational Sciences: Theory and Practice, vol.5,no. 1, p.135-146.

Keogh, B. \& Naylor, S. (1999). Concept cartoons, teaching and learning in science: an evaluation. International Journal of Science Education, 21(4), 431-446.

Keogh, B. \& Naylor, S. (2000). Concept Cartoons in Science Education. Cheshire, UK: Millgate House Publishers.

Kruit, Berg, \& Wu. (2012). Onderzoekend leren met concept cartoons in de basisschool. Getting children to design experiments through concept cartoons. Paper with a poster to be presented at the Onderwijs Research Dagen, Wageningen, $20-22$ juni 2012.

Naylor, S., Keogh, B. \& Downing, B. (2007). Argumentation and primary science. Research in Science Education, 37, 17-39.

Osborne, J., \& Dillon, J. (2008). Science Education in Europe: Critical Reflections. King's College London: The Nuffield Foundation

Osuská, L’. \& Pupala, B. (1996) „To je ako zázrak prírody“: fotosyntéza v žiakovom poňatí [„It is like a miracle of nature“: Photosynthesis in pupil's concept]. Pedagogika, 46(3), 214-223.

Prince, M. J. \& Felder, R. M. (2006). Inductive teaching and learning methods: definitions, comparisons, and research based. Journal of Engineering Education, 95(2), 123-138. Advance online publication. DOI: 10.1002/j.2168-9830.2006.tb00884.x

Rocard., M. Csermely, P., Jorde, D., Lenzen, D., Walberg-Henriksson, H. \& Hemmo, V. (2007). Science Education Now: A Renewed Pedagogy for the Future of Europe. Luxembourg. Office for Official Publications of the European Communities.

Stemle, S. (2001). An Introduction to Content Analysis, ERIC Document Reproduction Service No. ED 458 218). 23.12.2002'de ERIC veritabanından alınmı tır. Web üzerinde: http://www.eric.ed.gov

Titscher, Stefan, Meyer, Michael, Wodak, Ruth, \& Vetter, Eva (2000). Methods of text and discourse analysis (Bryan Jenner, Trans.). London: Sage. 


\section{Appendix A: Pretest/ Posttest}

Dear student,

I have for you a few questions that relate to everyday life. These questions and tasks are not easy - it is difficult also for adults. However, many times intuitive understanding of children is closer to the truth than complicated explanations of adults. You are not evaluated for this test so you are trying to answer these questions honestly - according to your beliefs and the in your words.

Name and surname:

Date:

Classroom:

1. Can sweater melted ice cubes? Explain why do you think so / why do you think no.

2. Why do we see better in the light than in the dark? Try to explain this situation. You can use an example from everyday life or from your experience.

3. The Indians used to put an ear to the rails. How do you explain it? Why, when and where they do that? Try to explain principle of operation of this phenomenon in the picture:

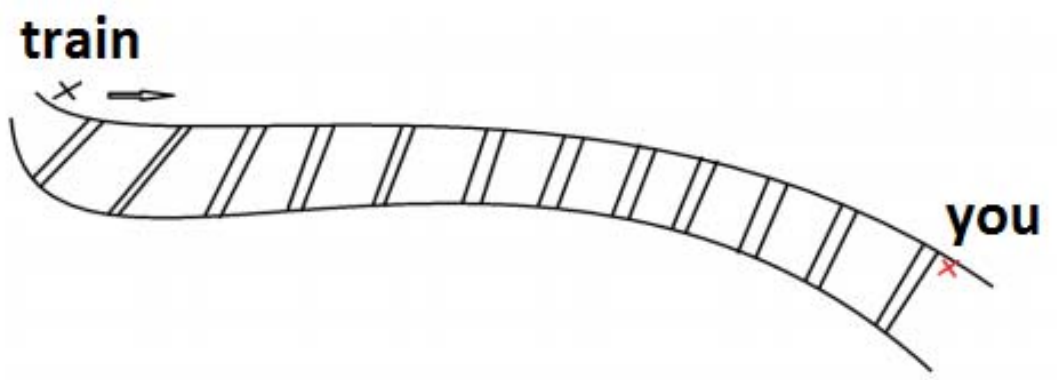

4. Why are we out of breath after running? Try to explain your idea of what is happening in your body when you're out of breath. You can help by drawing a picture.

5. If you throw an iron object in the water, it sinks. How is it possible that the boat floats when it is from the iron?

6. Can you ride on a sledge downhill in the summer as well as in the winter? Explain where would it go and why?

7. How will man fall with a parachute and a man without a parachute? Will be among them in their falls any difference? What force or what material or any other manner using of a parachute cause that man falls differently? You can also draw your explanation.

8. We use electricity every day: when watching TV, using the lift, when your mother cooks... We know that electricity is produced in power plants. Try to draw how electricity gets into your apartment from the power plant (8a)

Could you draw how electricity looks like according to you? (8b)

9. Why compass needle always points in one direction? What power according to you pulls / pushes a compass needle to point always in one direction? Where is the source of this power? You can also draw it if it's easier for you. Could you influence the direction of the compass needle to point elsewhere? If yes / no, how?

10. Why do magnets attract from one side and from the other side repel? Explain your answer and try to draw what you think is happening in magnets.

11. When you skates when you have to reflect more, when less and when may not be reflected. Do you think that stops when you do not reflections? Try to explain or draw what the happen when you accelerate/slow down.

12. Why Sun does not illuminate the entire surface of the Earth but only part of it? Try to draw your answer and explain it. 